\title{
MONITORING AND CONTROLLING METHANE HAZARD IN EXCAVATIONS IN HARD COAL MINES
}

\section{Introduction}

At present Polish mining regulations require the use of methane monitors with short or fast response times for current switchboard types when methane hazards co-exist with rock-burst hazards [1].

According to regulations the number and location of sensing devices for methane monitors should be consistent with the conditions present in any given monitored area.

In longwalls with a high output concentration, where mining is conducted with a high methane hazard, the location of methane sensors is not always sufficient. Additional sensors, not required by regulations, are frequently installed in the longwall. The location of these sensors depends on conditions in this area and the method of ventilation being used. In such cases it is also necessary to continuously monitor the methane hazard, ventilation, methane drainage and control over other hazards during the mining process considering all current safety parameters. The method of warning and informing miners of an existing hazard should also be included in the monitoring system of safety and production parameters [2].

Current technical devices and solutions offered by the producers of equipment for the control of methane hazards are as follows [11]:

- test for methane concentrations in areas with possible hazard, including a hazard caused by high methane concentrations under a chain conveyor,

- test for methane concentrations in methane drainage pipelines,

- possibility and necessity of automatic control of a methane drainage system depending on methane concentrations in pipelines and longwalls,

- test for air velocity in longwalls and methane concentration resulting from changes in air flow,

- condition of air stoppings, which affect the intensity of longwall ventilation and changes in aerodynamic potential distribution in the area of longwall,

- measurement of other gases' content (e.g. oxygen, carbon monoxide, carbon dioxide) if there is a possibility of such a hazard.

* AGH University of Science and Technology, Krakow; szlazak@agh.edu.pl; borowski@agh.edu.pl; swolkien@agh.edu.pl; mkorzec@agh.edu.pl 


\section{Methane hazard control in other countries}

Technical and legislative solutions concerning mining works during natural hazards depend on the range, method and intensity of mining works conducted. The specific character of mining works in a given country will often vary. Requirements concerning methane hazard control in selected countries, however, could also be applied to conditions in Polish mine workings. The next part of the article discusses the principles of methane hazard control in such selected countries.

\subsection{The United States of America}

All underground mines and surface plants are classified as belonging to one of the categories or sub-categories in order to protect workers from methane hazards. The criterion of methane hazard classification depends on the kind of minerals being mined, from which methane can be emitted into underground excavations as well as the type mining work being conducted. Regulations define six categories, out of which the $1^{\text {st }}, 2^{\text {nd }}$ and $5^{\text {th }}$ category to a great extent conform to the standards in hard coal mines. Within the categories, subcategories I-A, I-Band I-C are also defined [3].

A methane hazard is estimated by measuring methane concentrations both by means of tests conducted by a qualified person and by gas monitors.

Federal regulations (Title 30 Code of Federal Regulations, No. 30) concerning mineral resources [3] include work safety regulations in mines.

According to those regulations, methane concentration should be measured at least $30 \mathrm{~cm}$ from the roof, face, ribs and floor. In working places with air intake courses, methane concentration should be measured, and if a $1 \%$ methane concentration is reached or exceeded, electrically powered equipment in the affected area should be de-energized, mechanized equipment should be shut off (except intrinsically safe atmospheric monitoring systems) changes or adjustments should be made at once to the ventilation system to reduce the concentration of methane to less than $1 \%$ No other work is permitted in the affected area until the methane concentration is less than $1 \%$

When $1.5 \%$ or more methane is present in a work place or an air intake course, including an air course in which a belt conveyor is located, or in an area where mechanized mining equipment is being installed or removed; everyone except those referred to in $§ 104$ (c) of the Act should be withdrawn from the affected area; and except for intrinsically safe AMS, electrically powered equipment in the affected area should be disconnected at the power source. Sensing devices in excavations with intake air course to the affected area should send out warnings at about $1 \%$ concentration; and when the methane concentration reaches $1.5 \%$, sensors should send out both sound and visual signals.

In excavations with belt conveyors in the air intake, sensing devices should be located upwind in the belt entry at a defined distance from the mixing point where intake air is mixed with the belt air, at or near the tailpiece. In the case of auxiliary ventilation, a sensing device is installed about $90 \mathrm{~m}$ behind the suction fan in the return air flow split between 
a point in the return, opposite the section loading point, and where that split of air meets another split of air, or where the split of air is used to ventilate seals or worked-out areas.

When methane concentrations reach or exceed $1.5 \%$ in the return air flow from mined areas, the ventilating regulation system should be altered to reduce methane concentrations. Everyone except those referred to in $\$ 104$ (c) of the Act should be withdrawn from the affected area and (other than intrinsically safe AMS, equipment in the affected area should be de-energized, electric power should be disconnected at the power source, and other mechanized equipment (other than intrinsically safe AMS) should be shut off.

No other work is permitted in the affected area until methane concentration in the return air is less than $1.5 \%$ In case of using methane monitors, a sensing device should give off a warning sound and visual signal when methane concentration exceeds $1.5 \%$.

Methane monitors should be installed on all face cutting machines, continuous miners, longwall face equipment, loading machines, and other mechanized equipment used to extract or load coal within a working area. A sensing device for methane monitors on longwall shearing machines should be installed at the return air end of the longwall face. An additional sensing device should also be installed on the longwall shearing machine, downwind and as close to the cutting head as practicable. An alternative location or locations for sensing devices required on the longwall shearing machine may be approved in the ventilation plan. When the methane concentration at any methane monitor reaches $1 \%$, the monitor should give a warning signal. A methane monitor should then automatically de-energize electric equipment or shut down diesel-powered equipment on which it is mounted when the methane concentration at any methane monitor reaches $2 \%$. Methane concentrations in the bleeder split of air, immediately before the air in the split joins another split of air, or in a return air course should not exceed $2 \%$.

\subsection{Australia}

Coal deposits in Australia are characterized by various levels of methane content in coal. Where the methane content in a coal seam is equal to $9 \mathrm{~m}^{3} / \mathrm{Mg}$ or more are regarded as highly gaseous. Methane content of coal in coal deposits can even reach $25 \mathrm{~m}^{3} / \mathrm{Mg}$ [4].

Australian mining regulations [5] describe the principles of recognizing and controlling methane hazards, which also take into consideration the principles of using mining equipment, machinery and installations when methane hazards are present. The regulations also define obligations and measures which should be taken during a methane hazard. Permissible concentration limits, also defined in the regulations, which are a requirement that must be achieved by ventilation and technical means. There are separate mining regulations for mines in Queensland province and in New South Wales province.

\section{Mines in Queensland}

Mine ventilation systems must ensure that the concentration of methane in a mine not greater than $2.5 \%$. In ventilated systems there is always a possibility of methane concentrations increasing to above $2.5 \%$ if this concentration is short-term and the ventilation system is able to reduce the concentration below $2.5 \%$ quickly. 
Three explosion zones can be distinguished in mines.

1) Separate zone (not endangered) is where the methane concentration can't exceed $0.25 \%$. In this zone electrical equipment is allowed for work underground without explosion protection or with protection level of at least IP55 or AS 1939 can be used.

2) Zone 1 includes longwalls where there is or may be methane concentrations ranging from $0.5 \%$ to $2 \%$. In this zone electrical equipment allowed for work underground with explosion protection can be used.

3) Zone 0 includes longwalls where there is more methane in air and a methane concentration of $2 \%$ can be exceeded. Zone 1 becomes zone 0 if methane concentration exceeds $2 \%$. In this zone electrical equipment allowed for work underground with explosion protection Ex ia, Ex s or Ex I can be used.

Methane concentration in air intakes coming to zones 1 and 0 cannot be greater than $0.5 \%$. The volume of air flowing to the longwall face must have a methane dilution below $2 \%$ in the longwall face and below $1.25 \%$ at the exit from the auxiliary fans when exhausting ventilation is used.

Methane concentrations must be controlled at the outlet from a mining area, from an area of old, non sealed goafs or old longwalls, at the outlet from each gallery, where mined material is transported and in other places described in a methane safety plan. A gas monitoring system must have an independent supply in case electric supply is de-energized in the area.

At least one methane sensor must be located in the intake air course in front of zone 1or between two separate zones. When a methane concentration of $0.25 \%$ is exceeded, a detector must give off a visible signal. When a methane concentration $0.5 \%$ is exceeded, a detector de-energizesall machinery both in a separate zone and in zone 0 .

A methane sensor is also built into the return air flow channel both from the longwall and the ventilation area.

Sensing devices at the inlet and outlet from a longwall de-energize sensors when the methane concentration exceeds $2 \%$. Sensors at the outlet from an area or in main return air are included in a methane protection plan of a mine.

Roadway heading machines must also be equipped with at least one methane sensor of alarm level $1 \%$ and de-energize at $2 \%$. Sensors of a similar range are used with different machines and electric equipment.

A shearer must be equipped with at least one methane sensor with $1 \%$ alarm level and de-energizing a shearer at a level of $1.25 \%$ methane concentration and other equipment and machinery at methane concentrations above $2 \%$.

Battery or diesel-powered vehicles should also be equipped with methane sensors with a $1.0 \%$ alarm level and de-energize when methane concentration exceed $1.25 \%$. If the methane concentration exceeds $1 \%$ a vehicle operator has to withdraw it to an air stream with methane concentrations below $1 \%$. Vehicles especially adjusted to separate (not endangered zones) are also equipped with methane sensors with a $0.25 \%$ alarm level and de-energize at methane concentrations above $0.5 \%$. 
Methane concentrations in air flowing through the main or auxiliary fan cannot exceed permissible limits. The main or auxiliary fan must be monitored and a methane concentration detector must have a display and a visible alarm incase permissible methane limits are exceeded. The permissible methane limit in air flowing through underground auxiliary fans is $1.25 \%$.

\section{Mines in New South Wales}

A methane hazard zone is determined in mines. This zone includes all roadways with return air and roadways with air intakes at a distance of $100 \mathrm{~m}$ from a longwall face. The zone may be expanded if at least 2 methane sensors in an excavation indicate a methane concentration above $0.25 \%$ for at least 2 days.

A ventilation system must ensure the methane concentration in air intakes is not greater than $0.25 \%$ and in a hazard zone not greater than $2 \%$.

During development work, the permissible methane concentration limit in air intake leading to mining areas (at the inlet to explosion hazard zone) is $0.5 \%$. Air intakes leading to heading faces must ensure methane dilution below $2 \%$ in the heading face and below $1.25 \%$ methane at the outlet from auxiliary fans with exhausting ventilation.

In air intakes leading to mining areas, the permissible methane concentration limit is $0.25 \%$. In excavations with methane hazard, permissible methane concentration limit is $1 \%$.

In heading faces and longwalls the permissible methane concentration limits $2 \%$. Methane concentrations cannot exceed 2\% where intrinsically safe AMS are built in. Warning sensors with a visible alarm and sensors de-energizing machinery and electric equipment should be used in a methane safety system. In case of shearers, methane sensors de-energizing a shearer at $1.25 \%$ methane concentration are used.

Over roadway heading machinery, a methane sensor warning set at about $1 \%$ methane concentration and de-energizing machinery in the heading face will react when the methane concentration reaches $2 \%$ should be used.

Diesel-powered machinery used in the return air flow must be equipped with a methane sensor warning when the methane concentration reaches or exceeds $1 \%$.

\subsection{Russia and Ukraine}

Both in Russia the Ukraine mining works at longwalls can be conducted until the methane concentration reaches $1 \%$ [6]. Regulations specifically define what measures should be taken when the methane concentration exceeds $1 \%$. Methane concentrations in underground mine workings and pipelines must be carried out in accordance with the values given in Table 1. When calculating a ventilation system, maximum permissible methane concentration limits equal to $1 \%$ are assumed, no matter what measurement methods are used.

Methane sensors should be located at the headgate and at the tailgate of a longwall. However, in driven roadways, sensors should be placed in the heading face and should hang at $1.6 \mathrm{~m}$. An additional sensor should be built in $2 \mathrm{~m}$ in front of the fan. 
TABLE 1

Methane concentrations in underground mine workings and pipelines

\begin{tabular}{|l|c|}
\hline \multicolumn{1}{|c|}{ Air stream in a mine working or an air duct } & Methane concentration limit, [\%] \\
\hline Outlet from a driven roadway, chambers, depot & 1.0 \\
\hline Tailgate without AMS equipment & 1.0 \\
\hline Tailgate with AMS equipment & 1.3 \\
\hline In upcast shaft & 0.75 \\
\hline Inlet to a longwall and driven roadway, chamber, depot & 0.5 \\
\hline Local methane accumulation in longwalls and driver roadways & below 2.0 \\
\hline Outlet from an air mixing unit & below 2.0 \\
\hline Pipelines for methane drainage from injectors' station & 3.5 \\
\hline Methane drainage pipelines & below 3.5 and above 25 \\
\hline
\end{tabular}

\section{Estimation of methane hazard resulting from binding legal regulations in Poland}

Polish hard coal mines estimate a methane hazard in accordance with Polish Ordinance of the Minister in charge of the Economy of $28^{\text {th }}$ June 2002 on occupational safety and health, operation and special fire provisions in underground coal mines (legal status from $14^{\text {th }}$ August 2010) [1].

In Polish conditions, regulations define permissible methane concentration limits in mining air. Regulations define how and where methane concentration in mining air is controlled. The method for protecting electrical devices by means of methane monitors is also defined.

The next part of this article presents examples of the location of sensors in mining excavations with auxiliary ventilation and in longwalls.

\subsection{Mining excavations with auxiliary ventilation}

In methane fields, electric devices in a blind drift must be protected by methane monitor sensors de-energizing these devices. Detailed principles of building in methane sensors are defined in telemetric protection documentation of driven roadways. De-energizing auxiliary fans and de-energizing electrical devices in the heading face (except intrinsically safe atmospheric monitoring systems) should be used at all times.

In driven roadways which are more than $15 \mathrm{~m}$ long, de-energizing - registering methane sensors controlling methane concentrations under the roof of a drift are built in:

- when the heading face is ventilated by forcing auxiliary ventilation at a distance not greater than $10 \mathrm{~m}$ from the heading face, where methane concentration is greatest,

- when the heading face is ventilated by exhausting auxiliary ventilation between the inlet to the air duct and the heading face - at a distance not greater than $6 \mathrm{~m}$ from the heading face.

At the inlet to driven roadways over $25 \mathrm{~m}$ long a de-energizing - registering methane sensor is built in under the roof of a drift at a distance of $10 \mathrm{~m}$ to $15 \mathrm{~m}$ from the crossroads of an excavation with the main ventilation system. 
Sensors should de-energize a roadway heading machine when a $1 \%$ methane concentration is exceeded. Moreover, in fields with a II-IV category methane hazard, additional methane sensors taking continuous measurements, built in on the cutting head, capable of de-energizing when the methane concentration exceeds $2 \%$, should be used.

In the case of digging consolidated rocks that are not very likely to spark, roadways cannot be driven by a roadway heading machine if the methane concentration in the light of cross-section exceeds $0.5 \%$ or methane is accumulated under the roof at a distance to $50 \mathrm{~m}$ from the heading face.

All the remaining machinery and electrical-powered equipment are de-energized by sensors when a $2 \%$ methane concentration is exceeded when a ventilation system with forcing auxiliary ventilation is used. If exhausting auxiliary ventilation is used, methane sensors should de-energize electric devices when methane concentration exceeds $1 \%$.

In excavations with combined auxiliary ventilation, where dusting installation is used, methane sensors are also built in on the return air flow from the dusting installation and under the roof of a drift, in the zone of overlapping air ducts. These sensors are supposed to de-energize electric devices in excavation zones when the methane concentration exceeds $1 \%$.

In accordance with binding mining regulations [1] methane concentrations should be measured by portable methane sensors, which should be carried out by miners working at heading faces and methane engineers. Regulations define in detail the method and frequency of control.

Additional auxiliary ventilation systems should be used if the methane hazard increases above the forecasted methane-bearing capacity [7]. These devices are supposed to get rid of accumulated methane under the roof. In such cases, an air ejector, a cyclone, a perforated pump powered from a compressed air pipeline or an air ventilator are used. Air must be forced towards the spot where methane is emitted.

Examples of location of methane sensors in driven roadways with forcing auxiliary ventilation are presented in Figure 1 and with exhausting auxiliary ventilation in Figure 2.

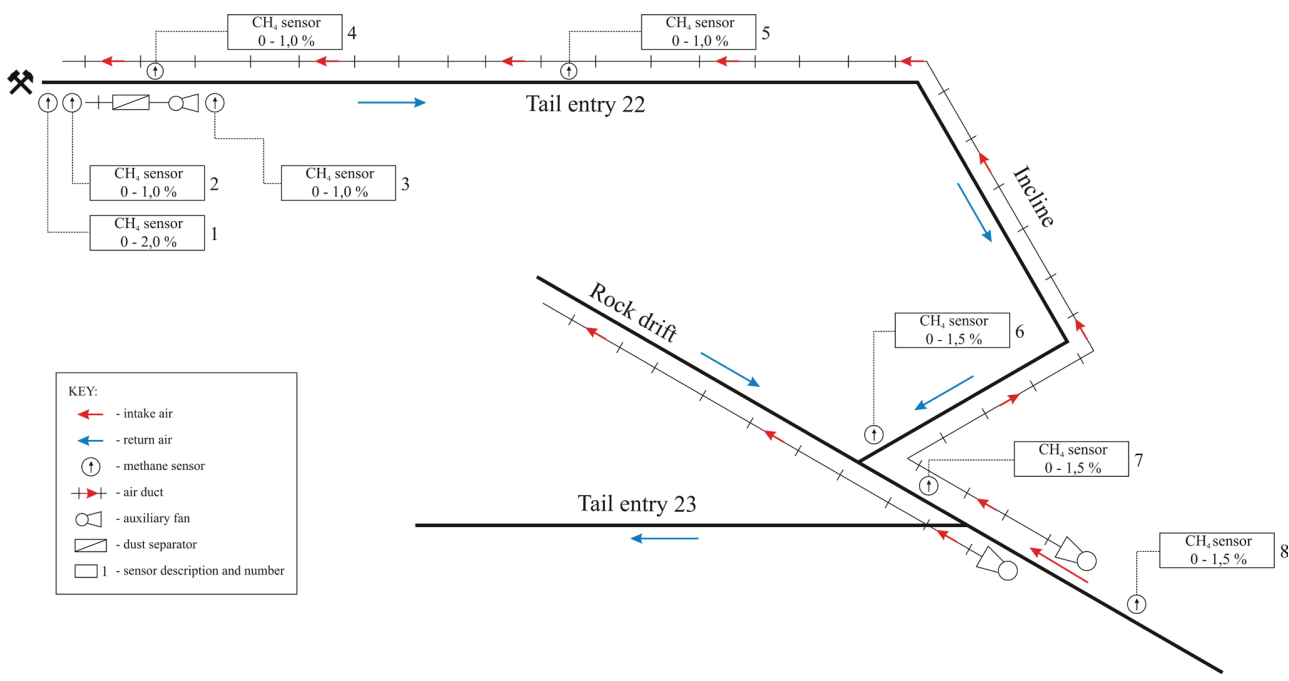

Fig. 1. Location of methane sensors in driven Tail entry 22 


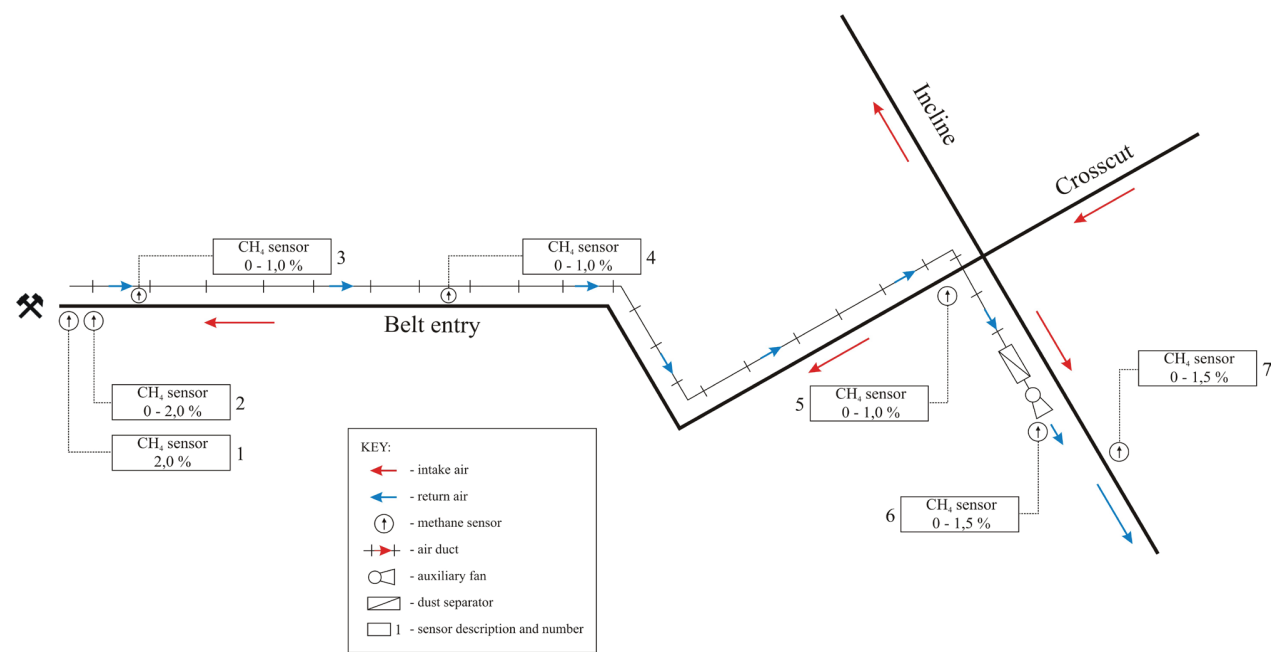

Fig. 2. Location of methane sensors in driven Belt entry 5

\subsection{Longwalls with $U$ and $Y$ ventilation systems}

Mining regulations [1] define in detail the location of methane monitor sensors in longwalls. The method of localizing methane sensors depends on a longwall ventilation system. The principles of localizing sensors are presented on the example of two longwalls ventilated by a $U$ ventilation system and one longwall ventilated by a Y system. Figure 3 presents the scheme of ventilation and location of methane sensors in longwall D-2, seam 409/3.

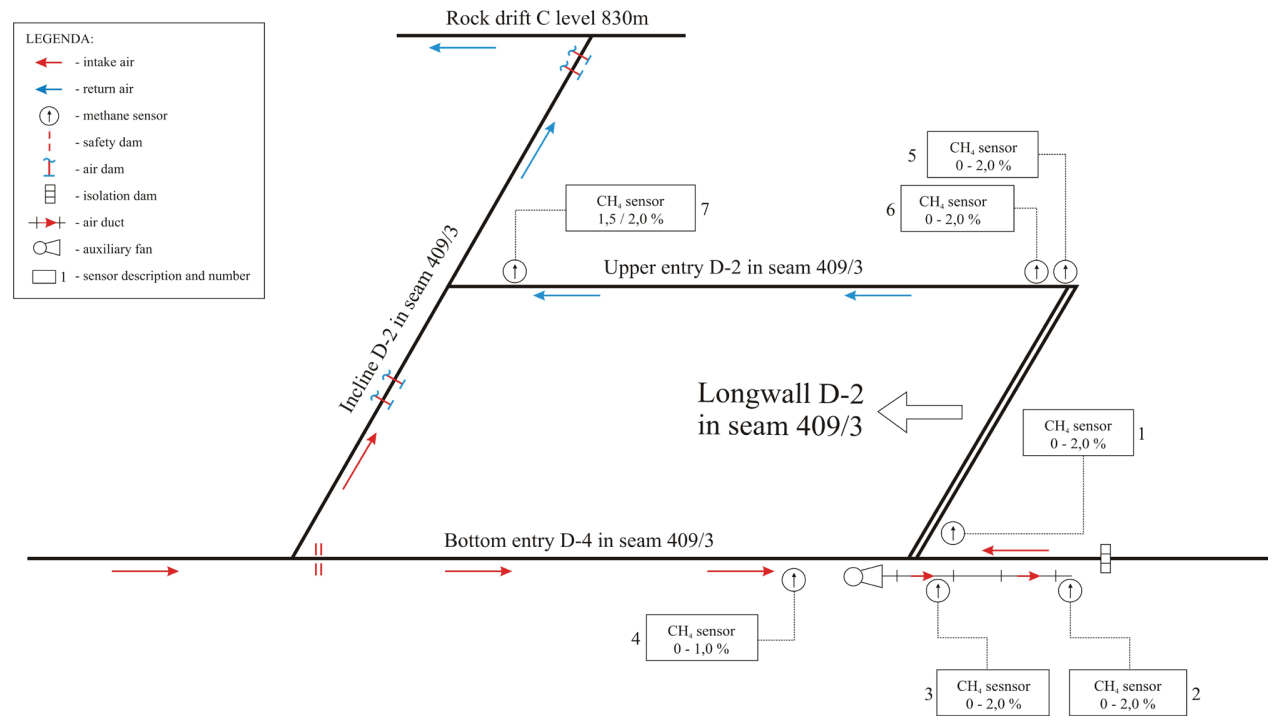

Fig. 3. Location of methane sensors in longwall D-2 in seam 409/3 
The location of methane monitor sensors may depend on local conditions in a given longwall as well as on the location of additional auxiliary ventilation equipment, which is built in order not to allow for the accumulation of hazardous methane concentrations at crossroads of longwalls with main gates. Figure 4 presents an example of the location of methane monitor sensors and auxiliary ventilation equipment at the tailgate of the longwall D-2.

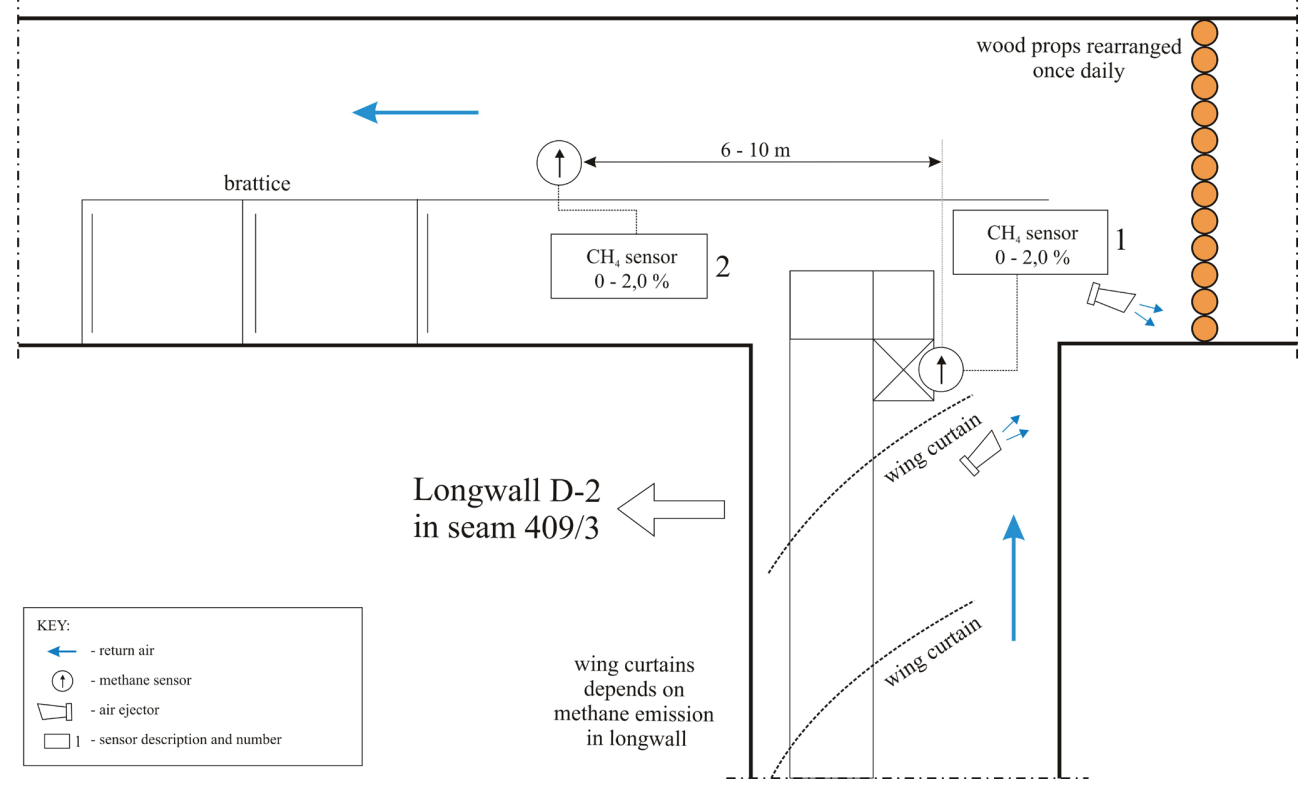

Fig. 4. Location of methane sensors and auxiliary ventilation equipment at the tailgate of longwall D-2 in seam 409/3

Auxiliary equipment includes brattices, splitting boards which are supposed to direct a part of air, in are as with low methane concentration, flowing in a longwall towards goaf [8-10] and to mix it with high methane content air flowing out of goaf. This is the most frequently used form of auxiliary ventilation equipment but it is not very effective, as the air velocity along a brattice or a splitting board is low and methane emissions from goaf are high. Therefore, the length of methane mixing course is very large.

Its effectiveness is greater if air flowing out of longwall goaf contains smaller amounts of methane, or if a splitting board is used simultaneously with other dynamic auxiliary ventilation equipment, such as air pumps or fans with a short air duct. When mining thin coal seams, air will flow out of the longwall to the crossroads with a roadway, generating a greater velocity at the roadway floor; however, air from longwall goaf can flow at the roof of a drift. Air mixing will take place when air pumps generating greater air spinning are used.

Figure 5 presents the location of both ventilation systems and methane sensors in longwall F-1 in seam 406/1 with $U$ ventilation system and Figure 6 presents the location of methane monitor sensors and auxiliary ventilation equipment in the tailgate of this longwall. 


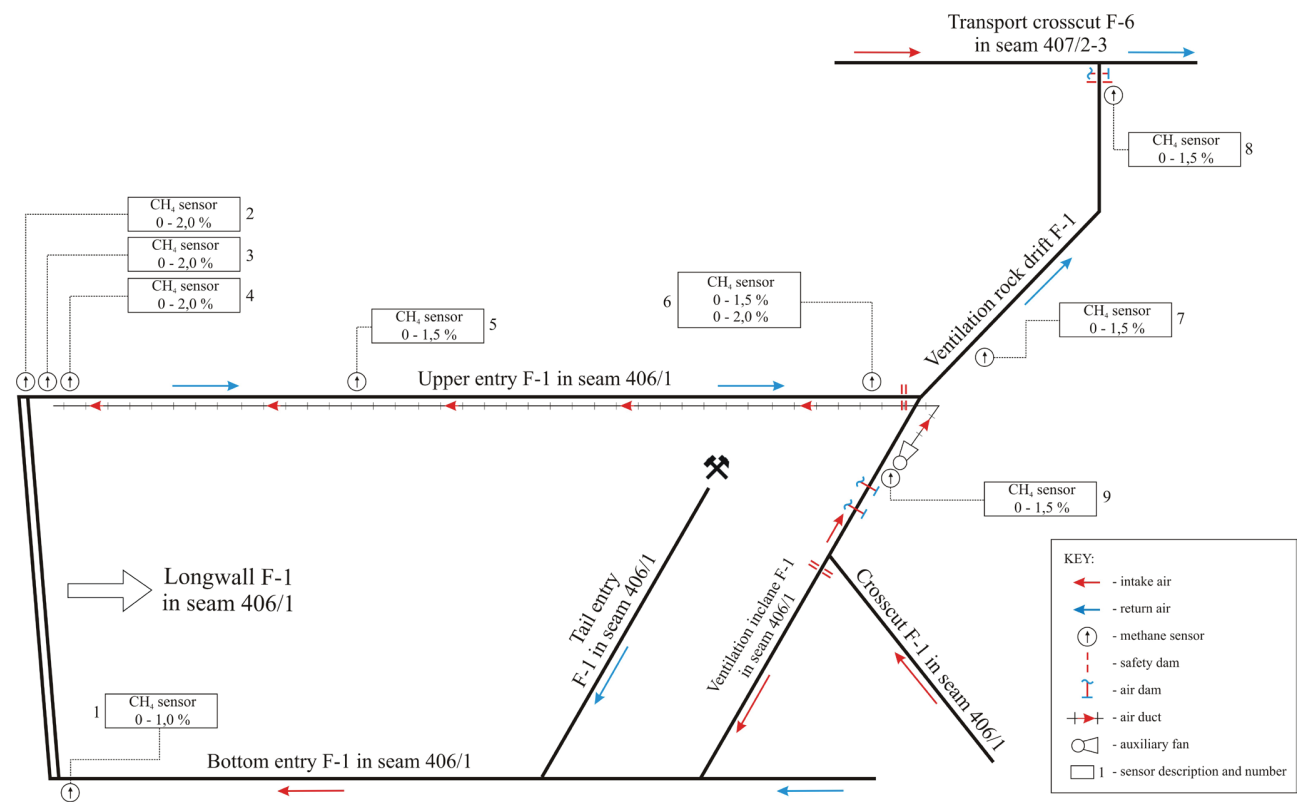

Fig. 5. Location of methane sensors at the tailgate of the longwall F-1 in seam 406/1

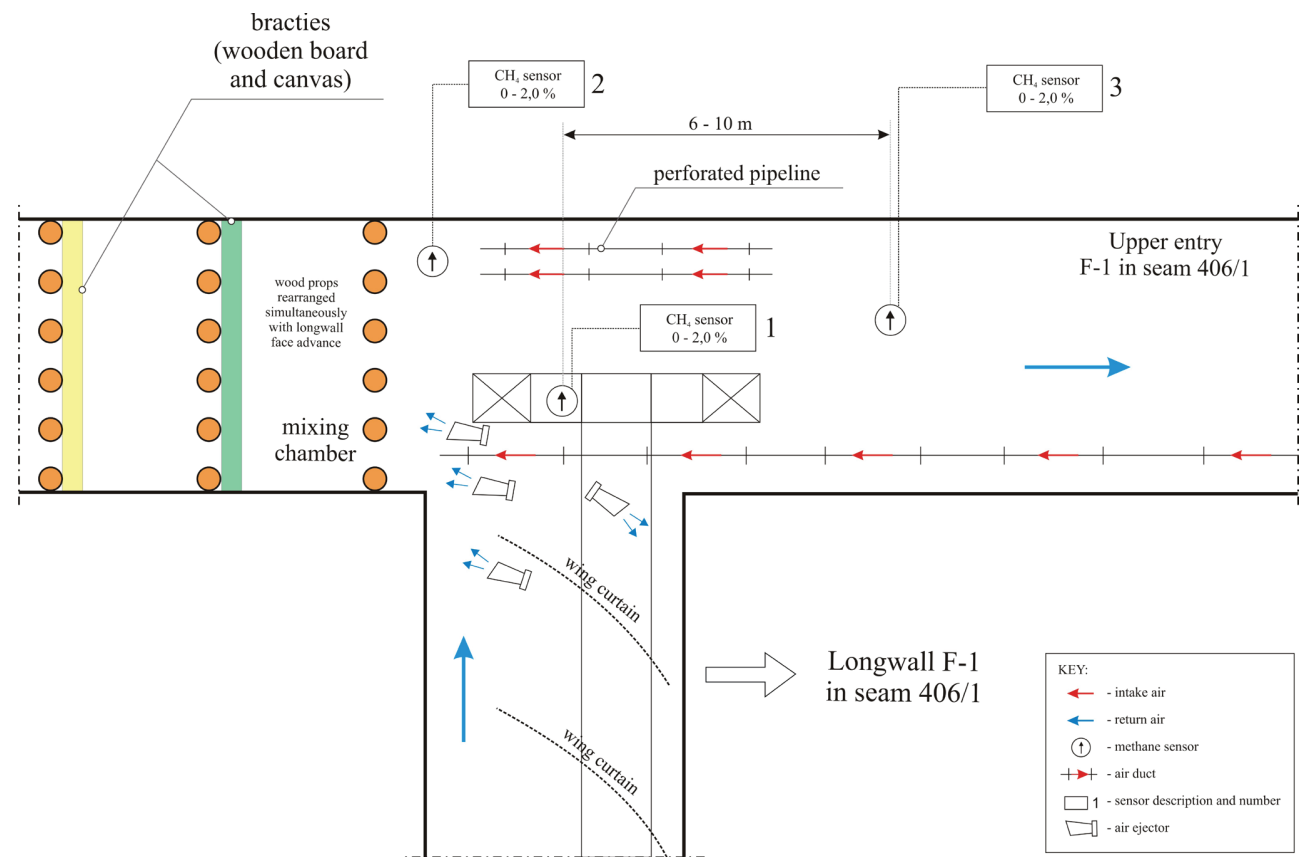

Fig. 6. Location of automatic methane sensors and auxiliary ventilation equipment at the tailgate of the longwall F-1 in seam 406/1 
Figure 7 presents the location of ventilation systems and methane sensors in longwall G-4 in seam $412 \nmid g$ with Y ventilation system.

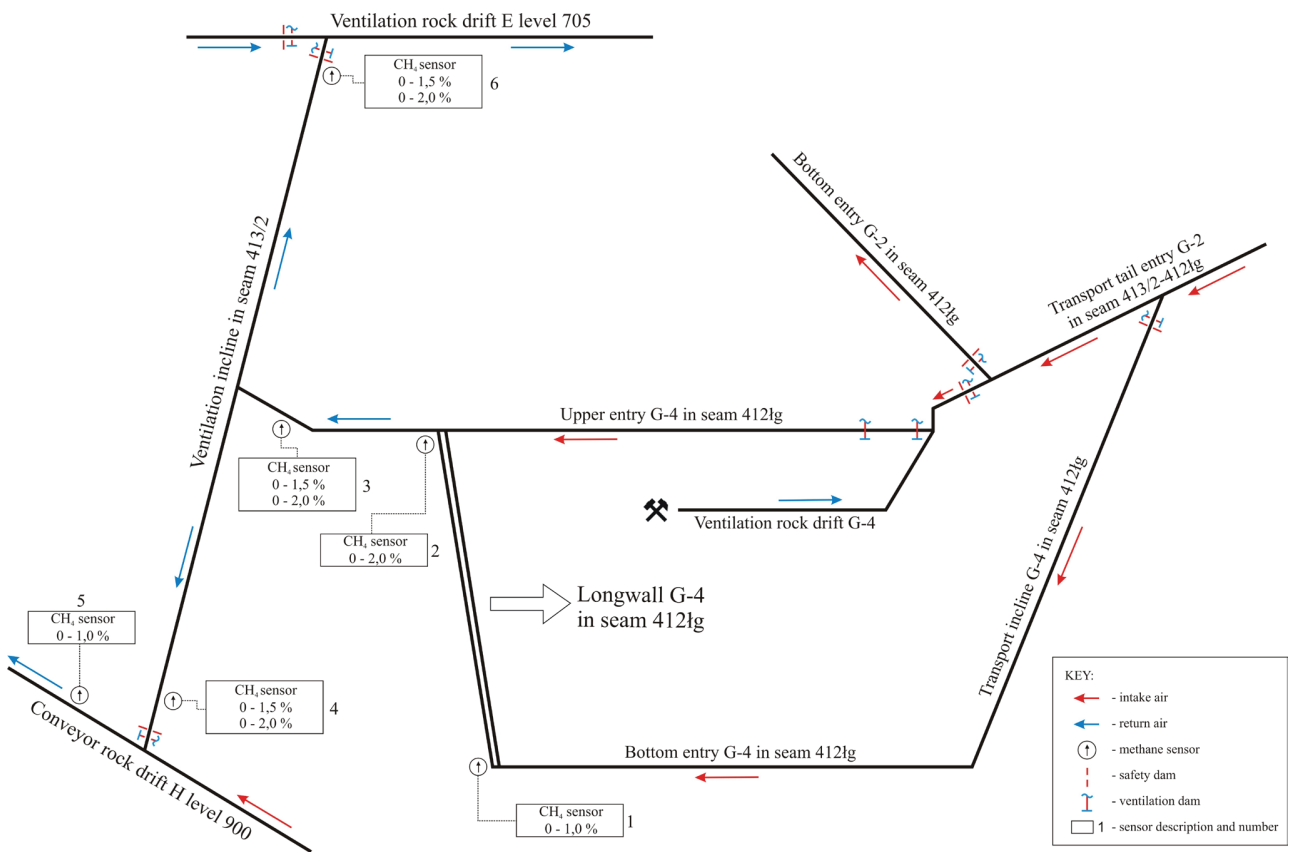

Fig. 7. Location of methane sensors in longwall G-4 in seam $412 \mathrm{~kg}$

\section{Summary}

In Polish hard coal mines the methane hazard is estimated in accordance with Polish Ordinance of the Minister in charge of the Economy of 28 June 2002 On Occupational Safety And Health, Operation And Special Fire Provisions In Underground Coal Mines [1].

The methane hazard is estimated mainly on the basis of the results of measurements taken by means of methane monitor sensors in longwalls and driven roadways. Sensors are located according to Polish Ordinance of the Minister in charge of the Economy and in case of areas with a great methane hazard additional sensors are located in extremely hazardous places. The location of sensors also depends on a longwall ventilation system.

Systems of auxiliary ventilation equipment are used in coal mines to avoid the accumulation of hazardous methane concentrations at the tailgate of longwalls.

In most countries mining coal, methane concentrations are controlled at the cross-section of excavations that have an active ventilation system and mining works in longwalls and driven roadways can be conducted when methane concentration range from $1 \%$ to $2 \%$. If the methane concentration exceeds this limit, mining by means of shearers and roadway heading machines must be stopped. Regulations in all countries define in detail the measures that should be taken when the methane concentration exceeds these limits. 
The differences in mining regulations in different countries result from using different mining systems, driving roadways and coal transport as well as different concentrations of methane contained in the material being extracted.

\section{Acknowledgment}

The article was prepared as a result of Strategic Project: "Improving safety of work in mines" financed by The National Centre for Research and Development, task 3, contract No. SP/K/3/143694/11.

\section{REFERENCES}

[1] Rozporządzenie Ministra Gospodarki z dnia 28 czerwca 2002 r. w sprawie bezpieczeństwa i higieny pracy, prowadzenia ruchu oraz specjalistycznego zabezpieczenia przeciwpożarowego w podziemnych zakładach górniczych.Dz.U.O2.139.1169 (Polish Ordinance of the Minister in charge of the Economy of 28 June 2002 on Occupational Safety and Health, Operation and Special Fire Provisions in Underground Coal Mines)

[2] Wasilewski S.: Stany nieustalone przepływu powietrza i stężenia metanu w wyrobiskach kopalnianych. Centrum Elektryfikacji i Automatyzacji Górnictwa EMAG, Katowice, nr 1 (9), 1998 (in Polish)

[3] Code of Federal Regulations - Title 30: Mineral Resources. Chapter I - Mine Safety And Health Administration, Department Of Labor. Electronic Code of Federal Regulations. e-CFR Data is current as of July 18, 2013 (http://www.gpo.gov/fdsys/browse/collectionCfraction?collectionCode=CFR)

[4] Kininmonth R.J., Baafi E.Y.: Australian Coal Mining Practice. Monograph 12 (third edition). Australian Institute of Mining and Metallurgy, Carlton Victoria 2009

[5] Coal Mining Safety and Health Regulation 2001. Queensland Subordinate Legislation 2001, No. 15. Coal Mining Safety and Health Act 1999, Australia (https://www.legislation.qld.gov.au/LEGISLTN/CURRENT/C/ CoalMinSHR01.pdf)

[6] Normativnye dokumenty po bezopasnosti, nadzornoj i razrešitel'noj deâtel'nostiv ugol'noj promyšlennosti, pravila bezopasnosti v ugol'nyh šahtah. PB 05-618-03, 2004 (http://www.znaytovar.ru/gost/2/PB_0561803_ Pravila_bezopasnost.html)

[7] Pawiński J., Roszkowski J., Szlazak N.: Zmiany koncentracji metanu w wyrobiskach korytarzowych. Archives of Mining Science, vol. 40, no. 3, 1995 (in Polish)

[8] Sułkowski J., Ngugen H. Dieu: Lokalizacja stref o wybuchowej koncentracji metanu w zrobach ściany zawałowej przewietrzanej przekątnie. Konferencja Naukowo-Techniczna „Zagrożenie metanowe w górnictwie", Ustroń, luty 1994

[9] Szlązak J., Szlazak N.: Filtracja powietrza w zrobach ścian zawałowych. Górnictwo, kwartalnik AGH, vol. 4, 2001, pp. 223-238 (in Polish)

[10] Szlązak J., Szlazak $N .:$ Ocena systemów przewietrzania wyrobisk ścianowych w kopalniach węgla kamiennego w warunkach zagrożenia metanowego i pożarowego. Materiały 3 Szkoły Aerologii Górniczej, Zakopane 2004 (in Polish) 